\title{
JOB INSECURITY, BURNOUT AND ORGANISATIONAL COMMITMENT AMONG EMPLOYEES OF A FINANCIAL INSTITUTION IN GAUTENG
}

\author{
J BOSMAN \\ JH BUITENDACH \\ K LABA \\ WorkWell: Research Unit for People, Policy and Performance \\ North-West University, Vaal Triangle Campus ${ }^{1}$
}

\begin{abstract}
The objective of this study was to investigate the relationship between job insecurity, burnout and organisational commitment of human resource workers $(N=146)$ in a financial institution. A cross-sectional survey design was used. The Job Insecurity Questionnaire, Maslach Burnout Inventory-General Survey, Organisational Commitment Questionnaire and a biographical questionnaire were administered. Job insecurity demonstrated a relationship with increased levels of burnout and decreased levels of organisational commitment. Job insecurity was found to hold predictive value with regard to exhaustion, cynicism, and reduced professional efficacy, as well as reduced affective and normative commitment (while controlling for the influence of background variables).
\end{abstract}

\section{OPSOMMING}

Die doelstelling van hierdie navorsing was om die verhouding tussen werksonsekerheid, uitbranding en organisasie verbondenheid van menslike hulpbronwerknemers $(N=146)$ in 'n finansiële instelling te ondersoek. 'n Dwarsneeopname-ontwerp is gebruik. Die Werksonsekerheidvraelys, Maslach Uitbrandingvraelys, Organisasieverbondenheidvraelys en 'n biografiese vraelys is afgeneem. Werksonsekerheid het 'n verband met verhoogde vlakke van uitbranding en verlaagde vlakke van organisasie verbondenheid getoon. Daar is bevind dat werksonsekerheid voorspellingswaarde inhou vir uitputting, sinisme en verminderde professionele doeltreffendheid, sowel as verminderde affektiewe en normatiewe organisasieverbondenheid (terwyl daar gekontroleer is vir die invloed van demografiese verskille).

Over the past four decades of the 20th century, the nature of work has changed dramatically. The 1960 's and 1970 's saw the introduction of new technology, such as the use of computers into the workplace (Sparks, Faragher \& Cooper, 2001). This was followed in the 1980's by a huge shift towards globalisation, with many organisations undergoing mergers, acquisitions, strategic alliances and privatisations. This entrepreneurial period resulted in increased economic competitiveness in international markets for those countries that embraced it (Cooper \& Jackson, 1997). In the 1990's, a major restructuring of work started to take place. Organisations in countries hit by recession were downsizing or delayering in an effort to survive. During the last decade, this trend for restructuring and downsizing has continued in many organisations, together with an increase in sub-contracting and outsourcing, in order to compete succesfully in the increasing competitive global market. Howard (1995) concurs that since the late 1970s, economic recession, industrial restructuring, technological change and an intensified global competition have dramatically changed the nature of work. In South Africa, the Pricewaterhouse Coopers annual survey on the banking industry indicates a substantial disturbance in the South African banking sector, which has seen the industry shed nearly 9000 jobs during 2003 (Whitfield, 2003).

Sparks, Faragher and Cooper (2001) add that there are fewer people at work, doing more and feeling less security and control in their jobs. Downsizing or 'rightsizing' appears to be the solution in organisational attempts at improving organisational effectiveness and reducing labour costs (Hitt, Keats, Harback \& Nixon, 1994). In addition, downsizing survivors have to do more with fewer resources, with an increasing work-load and uncertainty regarding task performance (Burke \& Nelson, 1998).

Job insecurity is said to be an individual's "expectations about continuity in a job situation" (Davy, Kinicki \& Scheck, 1997), "perception of a potential threat to continuity in his or her

Requests for copies should be addressed to: JH Buitendach, bpkjhb@puk.ac.za current job" (Heaney, Israel \& House, 1994) and "powerlessness to maintain desired continuity in a threatened job situation" (Greenhalgh \& Rosenblatt, 1984).

The underlying theme behind the various definitions is that job insecurity is a subjective phenomenon, i.e. that it is based on the individual's perceptions and interpretations of the immediate work environment (Hartley, Jacobson, Klandermans \& van Vuuren, 1991). Job insecurity refers to the anticipation of this stressful event in such a way that the nature and continued existence of one's job are perceived to be at risk, thereby implying that the feeling of job insecurity only occurs in the case of involuntary job loss. Hartley et al. (1991) state that job insecurity reflects a fundamental and involuntary change concerning the continuity and security within the employing organisation.

The two main themes identified within job insecurity are differentiated by Borg and Elizur (1992) as being (i) cognitive job insecurity, which refers to the likelihood of job loss and (ii) affective job insecurity, which refers to the fear of job loss. According to Hartley et al. (1991) job insecurity has the potential of being more distressing to the individual than job loss. Job loss is already known and the individual has to come to terms with the loss and cope with its outcomes. In the case of job insecurity, on the other hand, coping may be inhibited by the uncertainty of the event.

Maslach, Schaufeli and Leiter (2001) are of the opinion that the impact of the changing world of work is perhaps most evident in changes in the psychological contract. Employees are expected to give more in terms of time, effort, skills, and flexibility, whereas they receive less in terms of career opportunities, lifetime employment, and job security. The violation of the psychological contract between an employee and an organisation is likely to produce burnout, because it erodes the notion of reciprocity, which is crucial in maintaining well-being (Maslach et al., 2001). 
Burnout refers to employees' feelings that their physical and mental resources have been exhausted as a result of the continuous striving toward a work-related objective and is often the results of too much work pressure and stress, particularly if the pressure arises from unattainable work goals (Gerber, Nel \& van Dyk, 1999). Maslach and Pines (1977) state that in the case of burnout, the employee disengages him-/herself from clients and the job, therefore changing his/her attitude from caring to indifference. Exhaustion is considered to be the core indicator of burnout, being accompanied by four general symptoms: distress in the form of affective, cognitive, physical and behavioural symptoms, a sense of reduced effectiveness, decreased motivation and dysfunctional attitudes and behaviours (Schaufeli \& Buunk, 2002).

Burnout occurs when the organisational conditions are intolerable and unjust, to the extent that not even personal factors are sufficient to resist their effects. Burnout, in the opinions of Carrell et al. (1999), is the overall perception that one is giving more than one is receiving - in monetary rewards, recognition, support or advancement. Burnout can occur at all organisational levels, at all pay levels and in all age groups.

Emotional exhaustion is considered to be the first and most significant phase of burnout and is characterised by a lack of energy and a feeling that one's emotional resources depleted, which may coexist with feelings of frustration and tension (Cordes \& Dougherty, 1993). Depersonalisation is considered to be the second component of burnout. This phase of burnout typically occurs after emotional exhaustion and tends to be a direct response to the stressors of the job. It refers to an individual's personal detachment from work. For those who deal with people on a day-to-day basis this entails treating individuals as objects rather than people. Depersonalisation is characterised by a detached and an emotional callousness (Cordes \& Dougherty, 1993). Employees in the depersonalisation phase of burnout will take a cool, distant attitude toward work and the people on the job (Maslach \& Leiter, 1997). The final component of burnout, diminished personal accomplishment, is a decline in one's feelings of competence and successful achievement (Leiter \& Maslach, 1988). Individuals in this phase of burnout view themselves negatively in both their ability to perform the job and their ability to have positive personal interactions (Cordes \& Dougherty, 1993). Individuals experiencing diminished personal accomplishment trivialise the things that they are successful at and no longer feel they are able to make a difference through their work or personal interactions (Maslach \& Leiter, 1997). Cordes and Dougherty (1993) suggest that selfefficacy lay at the very centre of this construct, noting that variables making one feel lacking in control, helpless, inadequate or incompetent are likely to contribute to feelings of diminished personal accomplishment.

In her research, Storm (2002) found that Indian participants experienced the highest levels of exhaustion and cynicism, followed by white and black participants. Coloured participants experienced lowest levels of exhaustion and cynicism. No practically significant differences were found between the burnout scores of the black and white participants. No additional information pertaining to the relationship between demographic variables and engagement could be found. However, in a related sense, Wissing and van Eeden (2002) found significant differences between the scores of black and white groups on indices of psychological wellbeing, with the black group presenting with lower levels of psychological well-being, noting that these differences may result from different socio-cultural backgrounds, idiosyncratic factors and life circumstances. Antonovsky (1979) indicated that resistance resources are lower in historically black communities. Consequently people from these groups are more prone to stress and a lower sense of coherence. According to Wissing and Van Eeden (2002), it can be expected that the new socio-political dispensation that guarantees equity and equality for all, and ensures human rights through the Constitution, would eventually bring about higher levels of psychological well-being in the historically disadvantaged group. Regarding gender, Hobfoll (1989) is of the opinion that women have less access to resources that could help buffer stress and maintain wellness. Antonovsky (1991) argued that cultural, social and role patterns constructed for men and women, as well as lack of socio-economic value of women's contributions to society and the labour market play a large role in females' levels of psychological well-being. However, presently, one would have to interpret these findings within the context of the Employment Equity initiatives, striving for gender equality and female empowerment. For this reason, it would be necessary to consider the impact to demographic variables such as culture and gender when examining the impact of job insecurity on burnout.

People develop affective and attitudinal attachments toward their workplace over time, which evidences in high levels of commitment, satisfaction, and trust (Allen \& Meyer, 1990; Mowday, Steers \& Porter, 1979). Feelings of job insecurity may threaten these basic attachments, such as commitment, satisfaction and trust (De Witte, 1997; Rosenblatt \& Ruvio, 1996). Chow (1994) defines organisational commitment as the extent to which employees identify with their organisation and managerial goals, show a willingness to invest effort, participate in decision-making, and internalise organisational values.

The person's commitment to the organisation is reflected in three separable psychological states; being affective attachment, perceived costs, and obligation (Allen \& Meyer, 1990). Affective commitment is concerned with the extent to which the individual identifies with the organisation, whereas perceived costs (continuance commitment) concerns the individual's need to continue working for the organisation. Normative commitment or obligation is influenced by society's norms about the extent to which people ought to be committed to the organisation. Put simply, organisational commitment refers to people staying within the organisation because they want to (affective), because they need to (continuance), or because they feel they ought to (normative) (McDonald \& Makin, 2000).

In the opinions of McDonald and Makin (2000) affective commitment is influenced by the extent to which the individual's needs and expectations of the organisation are matched by their actual experiences, which links with the perceived reciprocal obligations of the psychological contract. Continuance commitment is determined by the perceived costs of leaving the organisation, of which "investments" and "sidebets" are important determinants. Normative commitment is a perceived obligation to stay with the organisation, which according to McDonald and Makin (2000), is strongly related to the "social exchange theory", where the person receiving a benefit is under a strong "normative" (i.e. rule governed) obligation to repay it back in some way.

Lok and Crawford (2001) found that age had a statistically significant positive effect on organisational commitment, as well as that tenure had a small negative influence on organisational commitment. Researchers such as Mathieu and Zajac (1990) and Michaels (1994) found that position tenure, organisational tenure and age were positively related to organisational commitment. De Cotiis and Summer (1987) found that educational level was negatively correlated to organisational commitment, which they explained in terms of more highly educated individuals having higher expectations, thus feeling that they are not being rewarded adequately, which diminishes organisational commitment levels. Based on these findings it would be necessary to control for the influence of demographic variables such as age, tenure and educational level when determining whether job insecurity holds predictive value with regard to organisational commitment. 
Employees with perceptions of low job security are more likely to engage in work withdrawal behaviours (Probst, 1999) and report reduced organisational commitment (Davy, Kinicki \& Scheck, 1991). Greenhalgh and Rosenblatt (1984) also found that the higher levels of job insecurity are, the lower the employees' organisational commitment and the greater the tendency to leave the organisation. In a South African study, Selepe (2004) obtained similar results in a petroleum/oil company.

The objective of this study is to investigate the relationship between job insecurity, burnout and organisational commitment. As noted by Rothmann (2003), tracking employees' effectiveness in coping with demands of the new world of work and stimulating their growth in areas that could possibly impact on individual well-being and organisational efficiency and effectiveness are crucial, hence the importance of this research. The following hypotheses are proposed:

H1: Job insecurity is associated with increased levels of exhaustion and holds predictive value with regard to exhaustion.

$\mathrm{H} 2$ : Job insecurity is associated with increased levels of cynicism and holds predictive value with regard to cynicism.

H3: Job insecurity is associated with decreased levels of professional efficacy and holds predictive value with regard to professional efficacy.

H4: Job insecurity is associated with decreased levels of affective commitment and holds predictive value with regard to affective commitment.

H5: Job insecurity is associated with decreased levels of normative commitment and holds predictive value with regard to normative commitment.

H6: Job insecurity is associated with decreased levels of continuance commitment and holds predictive value with regard to continuance commitment.

\section{RESEARCH DESIGN}

Research approach

A cross-sectional survey design was used in this research. Information collected is used to describe the population at that time and is appropriate for studying various groups at different stages of development (Burns \& Grove, 1993). According to Shaughnessy and Zechmeister (1997), this design is ideally suited to the descriptive and predictive functions associated with correctional research and is also less time consuming.

\section{Participants}

Stratified random samples $(\mathrm{N}=146)$ were taken from a financial institution. The population group consisted of workers from the human resources department within a financial setting. There are members from various human resource processes within the department.

The personnel from this target work group involve different types of positions, including (i) human resource consultants linked to clients (entry point consultants), who fulfil a generalist function within the human resource department, (ii) specialists involved with the different human resource processes, i.e. training and development, human capacity development, (iii) leaders within the different human resource functions, who fulfil their roles as indirect line managers together with the generalist and specialists functions and (iv) administrative assistants. The biographical data of the study sample is reflected in Table 1.
TABLE 1

Characteristics of The STUdy POPUlation $(\mathrm{N}=146)$

\begin{tabular}{|c|c|c|}
\hline Item & Category & Percentage \\
\hline \multirow[t]{2}{*}{ Sex } & Male & 53 \\
\hline & Female & 47 \\
\hline \multirow[t]{2}{*}{ Race } & White & 76 \\
\hline & Black & 24 \\
\hline \multirow[t]{5}{*}{ Age (years) } & 24 and younger & 02 \\
\hline & $25-35$ & 34 \\
\hline & $36-45$ & 35 \\
\hline & $46-55$ & 26 \\
\hline & 56 and older & 03 \\
\hline \multirow[t]{4}{*}{ Qualifications } & Grade $10-12$ & 20 \\
\hline & Diploma & 14 \\
\hline & Degree & 29 \\
\hline & Degree $^{+}$ & 37 \\
\hline \multirow[t]{7}{*}{ Years in company } & Less than $1 \mathrm{r}$ & 03 \\
\hline & $1-2$ & 06 \\
\hline & $3-4$ & 14 \\
\hline & $5-10$ & 26 \\
\hline & $11-15$ & 19 \\
\hline & $16-20$ & 18 \\
\hline & Longer than 20 & 15 \\
\hline \multirow[t]{7}{*}{ Years in present position } & Less than $1 \mathrm{r}$ & 08 \\
\hline & $1-2$ & 32 \\
\hline & $3-4$ & 37 \\
\hline & $5-10$ & 17 \\
\hline & $11-15$ & 06 \\
\hline & $16-20$ & - \\
\hline & $20+$ & - \\
\hline \multirow[t]{5}{*}{ Category } & Professional (Registered) & 29 \\
\hline & Semi-professional & 47 \\
\hline & Skilled & 24 \\
\hline & Semi-skilled & - \\
\hline & Unskilled (general worker) & - \\
\hline
\end{tabular}

Table 1 indicates that the majority of the study population (69\%) fell between the ages of $25-45$ years and held post graduate qualifications (37\%). Regarding tenure, the majority of the study population $(37 \%)$ had been employed in the organisation for three to four years. $29 \%$ of the workers indicated that they registered professionally, with $47 \%$ of the study population considering themselves to be semi-professionals.

\section{Measuring instruments}

The 11 items of the Job Insecurity Questionnaire (JIQ) (De Witte, 2000), which was used as a measure of job insecurity, summarise both the cognitive and affective dimensions of job insecurity and are arranged along a five-point scale, with one being "strongly disagree" and five representing strong agreement. An example of a question relating to cognitive job insecurity would be, "I think that I will be able to continue working here", whereas an example of a question relating to affective job insecurity would be, "I fear that I might lose my job". The items of the JIQ, measuring global job insecurity are reported to have a Cronbach alpha coefficient of 0,92 and both scales (cognitive and affective) were shown to be highly reliable, with the six items measuring cognitive job insecurity, displaying a Cronbach alpha coefficient of 0,90 ; and the five items of the affective job insecurity having a Cronbach alpha coefficient of 0,85 (De Witte, 2000). According to De Witte (2000) the content of these two scales do not overlap, but nevertheless have a high underlying correlation $(r=0,76)$. In 
terms of South African research, Heymans (2002) obtained an alpha coefficient of 0,81 for the JIQ and Elbert (2002) obtained an alpha coefficient of 0,84 .

The Maslach Burnout Inventory-General Survey (MBI-GS) (Maslach, Jackson \& Leiter, 1996) was used to measure burnout. The MBI-GS has three sub-scales: Exhaustion (five items; e.g. "I feel used up at the end of the workday"), Cynicism (five items, e.g. "I have become less enthusiastic about my work") and Professional Efficacy (six items, e.g. "In my opinion, I am good at my job"). Together the sub-scales of the MBI-GS provide a three-dimensional perspective on burnout. Internal consistencies (Cronbach alpha coefficients) reported by Maslach et al. (1996) varied from $\alpha=0,87$ to $\alpha=0,89$ for exhaustion, $\alpha=0,73$ to $\alpha=0,84$ for cynicism and $\alpha=0,76$ to $\alpha=0,84$ for professional efficacy. All items are scored on a 7-point frequency rating scale ranging from " 0 " (never) to " 6 " (daily). High scores on exhaustion and cynicism, and low scores on professional efficacy are indicative of burnout. In a South African study the following Cronbach alpha coefficients were obtained for the MBI-GS by Storm (2002): exhaustion: $\alpha=0,88$; cynicism: $\alpha=0,79$; professional efficacy: $\alpha=0,78$.

The Organisational Commitment Questionnaire (OCQ) of Allen and Meyer (1990) consists of 18 items rated on a 5-point Likert type scale ( $1=$ strongly disagree, $5=$ strongly agree). McDonald and Makin (2000), in their study of the organisational commitment of temporary staff in a UK organisation, found a reliability coefficient of 0,84. Allen and Meyer (1990) state that inter-item correlations between different samples were often above 0,90 , which shows that the combined factor is congruent. Cronbach alpha coefficients were consistently above $\alpha=0,80$ for every one of these sub-scales (Suliman \& Iles, 2000a). In a study done in South Africa, Heymans (2002) reported a total score of $\alpha=0,80, \alpha=0,69$ for the affective scale, $\alpha=0,53$ for the continuance scale and $\alpha=0,74$ for the normative scale.

\section{Analysis of data}

The statistical analysis was carried out with the help of the SPSSprogram (SPSS Inc, 2003). Cronbach alpha coefficients, interitem correlation coefficients and principal components analyses were used to assess the reliability and validity of the measuring instruments (Clark \& Watson, 1995). Descriptive statistics (e.g. means, standard deviations, skewness and kurtosis) were used to analyse the data. Pearson product-moment correlation coefficients were used to specify the relationships between the variables. A cut-off point of 0,30 (medium effect) and 0,50 (large effect) was set for the practical significance of correlation coefficients (Cohen, 1988). A multiple regression analysis, controlling for the influence of demographic variables, was conducted to determine whether job insecurity could predict burnout and organisational commitment.

\section{RESULTS}

\section{Interpretation}

A factor analysis was done to verify the construct validity of the components of the JIQ, where after it was decided that all 11 items would be used as one scale. In other words, use would be made of the total scale as opposed to an affective and cognitive subscale, given that the second factor presented with an eigenvalue less than 1 and did not have significant bearing. One factor was therefore retained, with the 11 items explaining $70 \%$ of the total variance within the questionnaire. From the 11 items, there were 3 items that had commonalities below 0.80 , ranging from $-0,67$ to $-0,69$. This does not have a high impact on the total variance score and the three items were retained. As indicated by Table 2, a Cronbach alpha coefficient of 0,92 was obtained for the JIQ, which compares favourably with the 0,70 cut-off point as set by Nunnally and Bernstein (1994). The inter-item correlation coefficient of job insecurity (total) was slightly high, but not unacceptable compared to the guideline of $0,15=\mathrm{r}=0,5$ (Clark \& Watson, 1995). The possible reason for this high score may be the fact that the items are narrowly defined. The scores appeared to be normally distributed ( more or less symmetrical, skewness $=0$ and kurtosis $=0$ ).

Table 2 indicates that acceptable reliability coefficients were obtained for the MBI-GS, as well its subscales. A factor analysis was done to verify the construct validity of the components of the questionnaire. Three factors, explaining $74 \%$ of the total variance, emerged. The total MGI-GS, as well as professional efficacy subscale, presented with acceptable average inter item correlations, although the mean inter item correlations of the exhaustion and cynicism subscales fell slightly above the 0,50 cut-off point. All scores appear to be normally distributed.

A factor analysis was done to verify the construct validity of the components of the OCQ. Three factors emerged, which together explained $68 \%$ of the total variance, with the commonalities ranging between $0,49-0,92$. As indicated by Table 2 , acceptable Cronbach alpha coefficients were obtained for the total OCQ, as well as its subscales. The mean inter-item correlation coefficient (r) of total OCQ, as well as the continuance and affective commitment subscales were found to be acceptable, although mean inter item correlation coefficient of the normative commitment subscale was found to be slightly high, although still acceptable. All scores appear to be normally distributed.

Next, the relationship between job insecurity, burnout and organisational commitment will be reported.

TABle 2

ALPHA COEFFICIENTS, INTER-ITEM CORRELATION COEFFICIENTS AND DESCRIPTIVE STATISTICS OF THE JIQ, MBI-GS AND OCQ

\begin{tabular}{|c|c|c|c|c|c|c|c|c|c|}
\hline Item & $\alpha$ & (r) & $N$ & Mean & SD & MIN & MAX & Skewness & Kurtosis \\
\hline Job Insecurity: Total & 0,92 & 0,66 & 146 & 2,83 & 10,21 & 1 & 5 & 0,21 & $-1,20$ \\
\hline Burnout: Total & 0,74 & 0,11 & 142 & 3,46 & 10.65 & 1 & 5 & $-0,30$ & 0,21 \\
\hline Burnout: Exhaustion & 0,96 & 0,84 & 142 & 3,06 & 7,23 & 0 & 6 & $-0,26$ & $-0,54$ \\
\hline Burnout: Cynicism & 0,90 & 0,64 & 142 & 2,78 & 7,09 & 0 & 6 & $-0,05$ & $-0,35$ \\
\hline Burnout: Professional Efficacy & 0,85 & 0,48 & 142 & 4,35 & 5,51 & 1 & 6 & $-0,39$ & 0,54 \\
\hline Organisational Commitment: Total & 0,92 & 0,40 & 143 & 2,74 & 13,26 & 1 & 5 & 0,12 & $-0,80$ \\
\hline Organisational Commitment: Affective & 0,87 & 0,50 & 143 & 2,87 & 5,87 & 1 & 5 & $-0,20$ & $-1,05$ \\
\hline Organisational Commitment: Continuance & 0,71 & 0.29 & 143 & 2,83 & 4,16 & 1 & 5 & 0,31 & $-0,33$ \\
\hline Organisational Commitment: Normative & 0,91 & 0,64 & 143 & 2,51 & 5,50 & 1 & 4 & 0,36 & $-0,81$ \\
\hline
\end{tabular}


TABLE 3

Product - MOMENT CORRelation COEFFicients

\begin{tabular}{|c|c|c|c|c|c|c|c|c|c|}
\hline & 1 & 2 & 3 & 4 & 5 & 6 & 7 & 8 & 9 \\
\hline 1. Job insecurity & - & & & & & & & & \\
\hline 2. MBI Exhaustion & $0,54^{*++}$ & - & & & & & & & \\
\hline 3. MBI Cynicism & $0,63^{*++}$ & $0,73 *++$ & - & & & & & & \\
\hline 4. MBI Professional efficacy & $-0,46^{*}+$ & $-0,51^{*++}$ & $-0,68^{*++}$ & - & & & & & \\
\hline 5. MBI total & $0,55^{*++}$ & $0,90^{*++}$ & $0,81 *++$ & $-0,29 *$ & - & & & & \\
\hline 6. OCQ Affective & $-0,59^{*}++$ & $-0,49 *+$ & $-0,65^{*++}$ & $0,62 *++$ & $-0,44^{*}+$ & - & & & \\
\hline 7. OCQ Continuance & 0,02 & $-0,13$ & $-0,10$ & 0,13 & $-0,09$ & $0,35^{*}+$ & - & & \\
\hline 8. OCQ Normative & $-0,50^{*++}$ & $-0,42 *+$ & $-0,51^{*++}$ & $0,47^{*}+$ & $-0,38^{*}+$ & $0,83^{*}++$ & $0,51^{*++}$ & - & . \\
\hline 9. OCQ total & $-0,46^{*}+$ & $-0,43 *+$ & $-0,53 *++$ & $0,51 *++$ & $-0,38 *+$ & $0,90 *++$ & $0,68 *++$ & $0,94 *++$ & - \\
\hline
\end{tabular}

* Statistically significant $\mathrm{p} \leq 0,01$

+ Correlation is practically significant $r=0,30$ (medium effect)

++ Correlation is practically significant $r=0,50$ (large effect)

As indicated by Table 3 , a practically significant correlation of large effect was obtained between job insecurity and emotional exhaustion, suggesting that higher levels of job insecurity are associated with higher levels of exhaustion. Furthermore, a practically significant correlation of large effect was obtained between job insecurity and cynicism, implying that increased levels of job insecurity are associated with increased levels of cynicism. A similar relationship was found between job insecurity and burnout in total. Lastly, a practically significant negative correlation of large effect was obtained with regard to job insecurity and professional efficacy, suggesting that higher levels of job insecurity are associated with perceptions of reduced professional efficacy. These findings support the opinions of Ferrie, Shipley, Marmot, Stansfield and Smith (1998), as well as Dekker and Schaufeli (1995), who note that job insecurity affects an employee to the extent where the worker experiences burnout.

Table 3 shows a practically significant negative correlation of large effect between job insecurity an affective commitment, as well normative commitment, implying that higher levels of job insecurity are associated with lower levels of affective and normative commitment to the organisation. The employees experiencing job insecurity thus identified less with their employing organisation and felt less obliged by societies' norms to remain employed within their organisation. The results reflected in Table 3 imply that no significant relationship exists between job insecurity and continuance commitment. These findings support the research findings of inter alia Ashford, Lee and Bobko (1989); Van Vuuren (1990); Davy, Kinicki and Scheck (1997); Lord and Hartley (1998) and Probst (1999), which indicated that organisational commitment will decrease when job insecurity prevails.

Next, regression analyses were conducted with job insecurity as an independent variable, also controlling for the effects of demographic variables such as culture, gender, age, qualifications and tenure.

The regression analysis reflected in Table 4 indicates that the demographic variables (culture in particular) contributed towards $3 \%$ of the variance in burnout. A R-value of 0,26 was obtained, which falls below the practical significance cut-off point $(0,30)$ and the model was not found to be statistically significant. Upon inclusion of job insecurity, the adjusted R2 increased by $28 \%$. A practically significant $\mathrm{R}$-value of large effect $(0,59)$ was obtained. The impact of culture disappeared in the second step, implying that the impact of culture on burnout may well run through job insecurity (see Table 4).
TABLE 4

REgReSSION ANALYSIS - DEMOgRAPHIC VARIABLES AND JOB INSECURITY: BURNOUT

\begin{tabular}{|c|c|c|c|c|c|}
\hline \multicolumn{6}{|c|}{ ANALYSIS OF VARIANCE } \\
\hline \multicolumn{6}{|c|}{ Model 1: Demographic variables } \\
\hline \multirow{3}{*}{$\begin{array}{l}\text { R: } 0,26 \\
R^{2}: 0,07 \\
\text { Adjusted } R^{2}: 0,03 \\
\text { Standard Error: } 10,49\end{array}$} & \multicolumn{2}{|c|}{ Source of variation } & $d f$ & $\begin{array}{l}\text { Sum of } \\
\text { squares }\end{array}$ & $\begin{array}{l}\text { Mean } \\
\text { Square }\end{array}$ \\
\hline & \multirow{2}{*}{\multicolumn{2}{|c|}{$\begin{array}{l}\text { Regression } \\
\text { Residual } \\
F=1,90 p=0,099\end{array}$}} & 5 & 1042,54 & 208,50 \\
\hline & & & 133 & 14633.90 & 110,03 \\
\hline \multicolumn{6}{|c|}{ Model 2: Demographic variables and job insecurity } \\
\hline \multirow{3}{*}{$\begin{array}{l}\text { R: } 0,59 \\
\mathrm{R}^{2}: 0,34 \\
\text { Adjusted } \mathrm{R}^{2}: 0,31 \\
\text { Standard Error: } 0,25\end{array}$} & \multicolumn{2}{|c|}{ Source of variation } & $d f$ & $\begin{array}{l}\text { Sum of } \\
\text { squares }\end{array}$ & $\begin{array}{l}\text { Mean } \\
\text { Square }\end{array}$ \\
\hline & \multirow{2}{*}{\multicolumn{2}{|c|}{$\begin{array}{l}\text { Regression } \\
\text { Residual } \\
F=11,47 p=0,000\end{array}$}} & 6 & 5370,78 & 895,13 \\
\hline & & & 32 & 10305,66 & 78,07 \\
\hline \multicolumn{6}{|c|}{ VARIABLES IN THE EQUATION } \\
\hline $\begin{array}{l}\text { INDEPENDENT S } \\
\text { VARIABLE }\end{array}$ & B & SEB & Beta & $\mathrm{t}$ & $\mathrm{p}$ \\
\hline Gender & 0,73 & 1,86 & 0,03 & 0,39 & 0,694 \\
\hline Culture & 6,04 & 2,23 & 0,24 & 2,71 & $0,008^{*}$ \\
\hline Age & $-1,30$ & 1,44 & $-0,11$ & $-0,91$ & 0,367 \\
\hline Qualifications & $-0,34$ & 0,82 & $-0,04$ & $-0,42$ & 0,677 \\
\hline Tenure & $-0,56$ & 0,82 & $-0,08$ & $-0,68$ & 0,496 \\
\hline Gender & 1,71 & 1,57 & 0,08 & 1,09 & 0,278 \\
\hline Culture & $-0,83$ & 2,09 & $-0,03$ & $-0,40$ & 0,694 \\
\hline Age & $-1,05$ & 1,21 & $-0,09$ & $-0,87$ & 0,387 \\
\hline Qualifications & $-0,41$ & 0,69 & $-0,04$ & $-0,59$ & 0,554 \\
\hline Tenure & $-0,62$ & 0,69 & $-0,09$ & $-0,90$ & 0,369 \\
\hline Job insecurity & 6,72 & 0,90 & 0,59 & 7,45 & 0,000 * \\
\hline
\end{tabular}

${ }^{*} \mathrm{p} \leq 0,05$ 
TABLE 5

REgRESSION ANALYSIS - DEMOGRAPHIC VARIABLES AND JOB SECURITY: EXHAUSTION

\begin{tabular}{|c|c|c|c|c|c|}
\hline \multicolumn{6}{|c|}{ ANALYSIS OF VARIANCE } \\
\hline \multicolumn{6}{|c|}{ Model 1: Demographic variables } \\
\hline \multirow{3}{*}{$\begin{array}{l}\text { R: } 0,23 \\
\mathrm{R}^{2}: 0,05 \\
\text { Adjusted } \mathrm{R}^{2}: 0,02 \\
\text { Standard Error: } 7,20\end{array}$} & \multicolumn{2}{|c|}{ Source of variation } & $d f$ & $\begin{array}{l}\text { Sum of } \\
\text { squares }\end{array}$ & $\begin{array}{l}\text { Mean } \\
\text { Square }\end{array}$ \\
\hline & \multirow{2}{*}{\multicolumn{2}{|c|}{$\begin{array}{l}\text { Regression } \\
\text { Residual } \\
F=1,48 p=0,200\end{array}$}} & 5 & 384,04 & 76,81 \\
\hline & & & 133 & 6889,201 & 51,80 \\
\hline \multicolumn{6}{|c|}{ Model 2: Demographic variables and job insecurity } \\
\hline \multirow{3}{*}{$\begin{array}{l}\text { R: } 0,59 \\
\mathrm{R}^{2}: 0,35 \\
\text { Adjusted } \mathrm{R}^{2}: 0,32 \\
\text { Standard Error: } 5,97\end{array}$} & \multicolumn{2}{|c|}{ Source of variation } & $d f$ & $\begin{array}{l}\text { Sum of } \\
\text { squares }\end{array}$ & $\begin{array}{l}\text { Mean } \\
\text { Square }\end{array}$ \\
\hline & \multirow{2}{*}{\multicolumn{2}{|c|}{$\begin{array}{l}\text { Regression } \\
\text { Residual } \\
F=11,98 p=0,000\end{array}$}} & 6 & 2564,01 & 427,34 \\
\hline & & & 132 & 4709,23 & 35,68 \\
\hline \multicolumn{6}{|c|}{ VARIABLES IN THE EQUATION } \\
\hline $\begin{array}{l}\text { INDEPENDENT } \\
\text { VARIABLES }\end{array}$ & B & SEB & Beta & $\mathbf{t}$ & $\mathrm{p}$ \\
\hline Gender & 1,09 & 1,28 & 0,08 & 0,85 & 0,395 \\
\hline Culture & 3,50 & 1,53 & 0,21 & 2,29 & 0,024 * \\
\hline Age & $-0,58$ & 0,99 & $-0,07$ & $-0,59$ & 0,558 \\
\hline Qualifications & 0,47 & 0,56 & 0,07 & 0,83 & 0,406 \\
\hline Tenure & $-0,27$ & 0,56 & $-0,06$ & $-0,47$ & 0,637 \\
\hline Gender & 1,78 & 1,06 & 0,12 & 1,68 & 0,096 \\
\hline Culture & $-1,38$ & 1,41 & $-0,08$ & $-0,97$ & 0,332 \\
\hline Age & $-0,40$ & 0,82 & $-0,05$ & $-0,49$ & 0,624 \\
\hline Qualifications & 0,42 & 0,47 & 0,07 & 0,90 & 0,368 \\
\hline Tenure & $-0,31$ & 0,47 & $-0,07$ & $-0,67$ & 0,506 \\
\hline Job insecurity & 4,77 & 0,61 & 0,62 & 7,82 & 0,000 * \\
\hline
\end{tabular}

${ }^{*} \mathrm{p} \leq 0,05$

The regression analysis reflected in Table 5 indicates that culture predicted $2 \%$ of the variance in exhaustion, although the model was not statistically significant. Upon inclusion of job insecurity, the R2 increased by $30 \%$. The impact of culture disappeared in the second step, implying once again that the impact of culture on exhaustion runs through job insecurity. In the second step, the impact of gender on exhaustion however became statistically significant. An R-value of large effect $(0,59)$ was obtained.

TABle 6

REgReSSION ANALYSIS - DEMOgRAPHIC VARIABLES AND JOB INSECURITY: CYNICISM

\begin{tabular}{|c|c|c|c|c|}
\hline \multicolumn{5}{|c|}{ ANALYSIS OF VARIANCE } \\
\hline \multicolumn{5}{|c|}{ Model 1: Demographic variables } \\
\hline \multirow{3}{*}{$\begin{array}{l}\text { R: } 0,30 \\
\mathrm{R}^{2}: 0,09 \\
\text { Adjusted } \mathrm{R}^{2}: 0,05 \\
\text { Standard Error: } 6,89\end{array}$} & Source of variation & $d f$ & $\begin{array}{l}\text { Sum of } \\
\text { squares }\end{array}$ & $\begin{array}{l}\text { Mean } \\
\text { Square }\end{array}$ \\
\hline & $\begin{array}{l}\text { Regression } \\
\text { Residual } \\
F=2,53 p=0,032\end{array}$ & 5 & 600,85 & 120,17 \\
\hline & & 133 & 6316,35 & 47,49 \\
\hline
\end{tabular}

\begin{tabular}{|c|c|c|c|c|c|}
\hline \multirow{3}{*}{$\begin{array}{l}\text { R: } 0,67 \\
\mathrm{R}^{2}: 0,45 \\
\text { Adjusted } \mathrm{R}^{2}: 0,43 \\
\text { Standard Error: } 5,35\end{array}$} & \multicolumn{2}{|c|}{ Source of variation } & $d f$ & $\begin{array}{l}\text { Sum of } \\
\text { squares }\end{array}$ & $\begin{array}{l}\text { Mean } \\
\text { Square }\end{array}$ \\
\hline & \multirow{2}{*}{\multicolumn{2}{|c|}{$\begin{array}{l}\text { Regression } \\
\text { Residual } \\
F=18,30 p=0,000\end{array}$}} & 6 & 3140,72 & 523,45 \\
\hline & & & 132 & 3776,48 & 28,61 \\
\hline \multicolumn{6}{|c|}{ VARIABLES IN THE EQUATION } \\
\hline $\begin{array}{l}\text { INDEPENDENT } \\
\text { VARIABLES }\end{array}$ & B & SEB & Beta & $t$ & $\mathrm{p}$ \\
\hline Gender & 1,23 & 1,22 & 0,09 & 1,01 & 0,315 \\
\hline Culture & 4,49 & 1,46 & 0,27 & 3,07 & 0,003 * \\
\hline Age & $-0,57$ & 0,95 & $-0,07$ & $-0,61$ & 0,546 \\
\hline Qualifications & 0,45 & 0,54 & 0,07 & 0,83 & 0,410 \\
\hline Tenure & $-0,49$ & 0,54 & $-0,11$ & $-0,90$ & 0,368 \\
\hline Gender & 1,98 & 0,95 & 0,14 & 2,08 & 0,039 * \\
\hline Culture & $-0,77$ & 1,27 & $-0,05$ & $-0,61$ & 0,546 \\
\hline Age & $-0,38$ & 0,73 & $-0,05$ & $-0,52$ & 0,604 \\
\hline Qualifications & 0,39 & 0,42 & 0,06 & 0,94 & 0,349 \\
\hline Tenure & $-0,54$ & 0,42 & $-0,12$ & $-1,28$ & 0,203 \\
\hline Job insecurity & 5,14 & 0,55 & 0,68 & 9,42 & 0,000 * \\
\hline
\end{tabular}

${ }^{*} \mathrm{p} \leq 0,05$

The regression analysis as indicated in Table 6 indicates that culture predicted $5 \%$ of the variance in cynicism. An R-value of medium effect $(0,30)$ was obtained. Upon inclusion of job insecurity, the R2 increased by $38 \%$ and once again the impact of culture disappeared in the second step and gender became significant. A practically significant R-value of large effect $(0,67)$ was obtained.

TABLE 7

REgRESSION ANALYSIS - DEMOgRAPHIC VARIABLES AND JOB SECURITy: Professional efFicaCy

\begin{tabular}{|c|c|c|c|c|}
\hline \multicolumn{5}{|c|}{ ANALYSIS OF VARIANCE } \\
\hline \multicolumn{5}{|c|}{ Model 1: Demographic variables } \\
\hline \multirow{3}{*}{$\begin{array}{l}\text { R: } 0,32 \\
\mathrm{R}^{2}: 0,10 \\
\text { Adjusted } \mathrm{R}^{2}: 0,07 \\
\text { Standard Error: } 5,28\end{array}$} & Source of variation & $d f$ & $\begin{array}{l}\text { Sum of } \\
\text { squares }\end{array}$ & $\begin{array}{c}\text { Mean } \\
\text { Square }\end{array}$ \\
\hline & $\begin{array}{l}\text { Regression } \\
\text { Residual } \\
F=2,99 p=0,014\end{array}$ & 5 & 415,93 & 83,19 \\
\hline & & 133 & 3700,16 & 27,82 \\
\hline
\end{tabular}

\begin{tabular}{|c|c|c|c|c|}
\hline \multicolumn{5}{|c|}{ Model 2: Demographic variables and job insecurity } \\
\hline \multirow{3}{*}{$\begin{array}{l}\text { R: } 0,58 \\
\mathrm{R}^{2}: 0,34 \\
\text { Adjusted } \mathrm{R}^{2}: 0,31 \\
\text { Standard Error: } 4,54\end{array}$} & Source of variation & $d f$ & $\begin{array}{l}\text { Sum of } \\
\text { squares }\end{array}$ & $\begin{array}{l}\text { Mean } \\
\text { Square }\end{array}$ \\
\hline & $\begin{array}{l}\text { Regression } \\
\text { Residual } \\
F=11,29 p=0,000\end{array}$ & 6 & 1395,49 & 232,58 \\
\hline & & 132 & 2720,60 & 20,61 \\
\hline
\end{tabular}

\begin{tabular}{lccccc}
\hline \multicolumn{7}{c}{ VARIABLES IN THE EQUATION } & & \\
\hline $\begin{array}{l}\text { INDEPENDENT } \\
\text { VARIABLES }\end{array}$ & $\mathbf{B}$ & SEB & Beta & T & p \\
\hline Gender & & & & & \\
Culture & $-1,59$ & 0,94 & $-0,15$ & $-1,70$ & 0,092 \\
Age & $-1,95$ & 1,12 & $-0,15$ & $-1,74$ & 0,084 \\
Qualifications & $-0,15$ & 0,72 & $-0,03$ & $-0,21$ & 0,835 \\
Tenure & -1.26 & 0,41 & $-0,26$ & $-3,05$ & $0,003^{*}$ \\
Gender & 0,19 & 0,41 & 0,06 & 0,47 & 0,639 \\
Culture & $-2,05$ & 0,81 & $-0,19$ & $-2,54$ & $0,012 *$ \\
Age & 1,32 & 1,07 & 0,10 & 1,23 & 0,223 \\
Qualifications & $-0,27$ & 0,62 & $-0,05$ & $-0,43$ & 0,666 \\
Tenure & $-1,23$ & 0,36 & $-0,25$ & $-3,45$ & 0,001 * \\
Job insecurity & 0,23 & 0,36 & 0,06 & 0,63 & 0,529 \\
\hline
\end{tabular}


As indicated by Table 7 , gender, race, and qualification predicted $7 \%$ of the variance in professional efficacy. A practically significant R-value of medium effect $(0,32)$ was obtained. In the second step, the R2 increased by $24 \%$. The impact of gender and qualification remained statistically significant, although the impact of culture became statistically insignificant. An R-value of large effect $(0,58)$ was obtained.

TABLE 8

REgRESSION ANALYSIS - DEMOgRAPHIC VARIABLES AND JOB INSECURITY: ORGANISATIONAL COMMITMENT

\begin{tabular}{|c|c|c|c|c|c|}
\hline \multicolumn{6}{|c|}{ ANALYSIS OF VARIANCE } \\
\hline \multicolumn{6}{|c|}{ Model 1: Demographic variables } \\
\hline \multirow{3}{*}{$\begin{array}{l}\text { R: } 0,33 \\
\mathrm{R}^{2}: 0,11 \\
\text { Adjusted } \mathrm{R}^{2}: 0,07 \\
\text { Standard Error: } 12,82\end{array}$} & \multicolumn{2}{|c|}{ Source of variation } & $d f$ & $\begin{array}{l}\text { Sum of } \\
\text { squares }\end{array}$ & $\begin{array}{c}\text { Mean } \\
\text { Square }\end{array}$ \\
\hline & \multirow{2}{*}{\multicolumn{2}{|c|}{$\begin{array}{l}\text { Regression } \\
\text { Residual } \\
F=3,18 p=0,010\end{array}$}} & 5 & 2614,23 & 522,85 \\
\hline & & & 134 & 22027,51 & 164,38 \\
\hline \multicolumn{6}{|c|}{ Model 2: Demographic variables and job insecurity } \\
\hline \multirow{3}{*}{$\begin{array}{l}\text { R: } 0,64 \\
\mathrm{R}^{2}: 0,41 \\
\text { Adjusted } \mathrm{R}^{2}: 0,39 \\
\text { Standard Error: } 10,42\end{array}$} & \multicolumn{2}{|c|}{ Source of variation } & $\mathrm{df}$ & $\begin{array}{l}\text { Sum of } \\
\text { squares }\end{array}$ & $\begin{array}{l}\text { Mean } \\
\text { Square }\end{array}$ \\
\hline & \multirow{2}{*}{\multicolumn{2}{|c|}{$\begin{array}{l}\text { Regression } \\
\text { Residual } \\
F=11,47 p=0,000\end{array}$}} & 6 & 10206,06 & 1701,01 \\
\hline & & & 133 & 14435,68 & 108,54 \\
\hline \multicolumn{6}{|c|}{ VARIABLES IN THE EQUATION } \\
\hline $\begin{array}{l}\text { INDEPENDENT } \\
\text { VARIABLES }\end{array}$ & B & SEB & Beta & $\mathrm{t}$ & $\mathrm{p}$ \\
\hline Gender & 0,97 & 2,27 & 0,036 & 0,43 & 0,670 \\
\hline Culture & $-1,42$ & 2,72 & $-0,046$ & $-0,52$ & 0,602 \\
\hline Age & $-0,47$ & 1,76 & $-0,031$ & $-0,26$ & 0,792 \\
\hline Qualifications & $-2,66$ & 1,00 & $-0,223$ & $-2,65$ & 0,009 * \\
\hline Tenure & 1,91 & 1,00 & 0,223 & 1,91 & 0,058 \\
\hline Gender & $-0,34$ & 1,85 & $-0,01$ & $-0,18$ & 0,854 \\
\hline Culture & 7,66 & 2,46 & 0,25 & 3,11 & $0,002 *$ \\
\hline Age & $-0,79$ & 1,43 & $-0,05$ & $-0,55$ & 0,582 \\
\hline Qualifications & $-2,57$ & 0,82 & $-0,22$ & $-3,15$ & $0,002 *$ \\
\hline Tenure & 1,99 & 0,81 & 0,23 & 2,45 & $0,016^{*}$ \\
\hline Job insecurity & $-8,89$ & 1,06 & $-0,63$ & $-8,36$ & $0,000^{*}$ \\
\hline
\end{tabular}

${ }^{*} \mathrm{p} \leq 0,05$

The regression analysis reflected in Table 8 indicates that the demographic variables (qualification and tenure) contributed towards $7 \%$ of the variance in commitment. A R-value of medium effect $(0,32)$ was obtained. Upon inclusion of job insecurity, the adjusted R2 increased by $32 \%$ and culture also appeared to hold some predictive value with regard to commitment levels (although the impact of culture was not significant in the first step). A practically significant $\mathrm{R}$-value of large effect $(0,64)$ was obtained. Qualification and tenure thus had predictive value with regard to organisational commitment, as did job insecurity and culture.
TABLE 9

REgRESSION ANALYSIS - DEMOGRAPHIC VARIABLES AND JOB INSECURITY: AFFECTIVE COMMITMENT

\begin{tabular}{|c|c|c|c|c|c|}
\hline \multicolumn{6}{|c|}{ ANALYSIS OF VARIANCE } \\
\hline \multicolumn{6}{|c|}{ Model 1: Demographic variables } \\
\hline \multirow{3}{*}{$\begin{array}{l}\text { R: } 0,29 \\
\mathrm{R}^{2}: 0,08 \\
\text { Adjusted } \mathrm{R}^{2}: 0,05 \\
\text { Standard Error: } 5,75\end{array}$} & \multicolumn{2}{|c|}{ Source of variation } & $d f$ & $\begin{array}{l}\text { Sum of } \\
\text { squares }\end{array}$ & $\begin{array}{l}\text { Mean } \\
\text { Square }\end{array}$ \\
\hline & \multirow{2}{*}{\multicolumn{2}{|c|}{$\begin{array}{l}\text { Regression } \\
\text { Residual } \\
F=2,37 p=0,042\end{array}$}} & 5 & 392,32 & 78,46 \\
\hline & & & 134 & 4432,67 & 33,08 \\
\hline \multicolumn{6}{|c|}{ Model 2: Demographic variables and job insecurity } \\
\hline \multirow{3}{*}{$\begin{array}{l}\text { R: } 0,68 \\
\mathrm{R}^{2}: 0,46 \\
\text { Adjusted } \mathrm{R}^{2}: 0,44 \\
\text { Standard Error: } 4,41\end{array}$} & \multicolumn{2}{|c|}{ Source of variation } & $d f$ & $\begin{array}{l}\text { Sum of } \\
\text { squares }\end{array}$ & $\begin{array}{l}\text { Mean } \\
\text { Square }\end{array}$ \\
\hline & \multirow{2}{*}{\multicolumn{2}{|c|}{$\begin{array}{l}\text { Regression } \\
\text { Residual } \\
F=19,19 p=0,000\end{array}$}} & 6 & 2238,75 & 373,13 \\
\hline & & & 133 & 2586,24 & 19,45 \\
\hline \multicolumn{6}{|c|}{ VARIABLES IN THE EQUATION } \\
\hline $\begin{array}{l}\text { INDEPENDENT } \\
\text { VARIABLES }\end{array}$ & B & SEB & Beta & $\mathrm{t}$ & $\mathrm{p}$ \\
\hline Gender & $-0,68$ & 1,02 & $-0,06$ & $-0,67$ & 0,507 \\
\hline Culture & $-2,69$ & 1,22 & $-0,20$ & $-2,21$ & 0,029 * \\
\hline Age & 0,10 & 0,79 & 0,02 & 0,13 & 0,897 \\
\hline Qualifications & $-0,66$ & 0,45 & $-0,13$ & $-1,46$ & 0,146 \\
\hline Tenure & 0,76 & 0,45 & 0,20 & 1,69 & 0,094 \\
\hline Gender & $-1,32$ & 0,78 & $-0,11$ & $-1,69$ & 0,094 \\
\hline Culture & 1,79 & 1,04 & 0,13 & 1,71 & 0,089 \\
\hline Age & $-0,06$ & 0,61 & $-0,01$ & $-0,10$ & 0,924 \\
\hline Qualifications & $-0,61$ & 0,35 & $-0,12$ & $-1,77$ & 0,078 \\
\hline Tenure & 0,80 & 0,35 & 0,21 & 2,32 & 0,022 * \\
\hline Job insecurity & $-4,39$ & 0,45 & $-0,70$ & $-9,74$ & $0,000^{*}$ \\
\hline
\end{tabular}

${ }^{*} \mathrm{p} \leq 0,05$

As indicated by Table 9 , culture predicted $5 \%$ of the variance in affective commitment. A R-value falling very slightly below the 0,30 cut-off point was obtained $(0,29)$ and the model was statistically significant. Upon inclusion of job insecurity, the R2 increased by 39\% and an R-value of large effect $(0,68)$ was obtained. In the second step, the influence of culture however became statistically insignificant, but the influence of qualifications and tenure (which were statistically insignificant in the first step) became statistically significant.

Table 10 indicates that qualifications predicted $5 \%$ of the variance in normative organisational commitment. An Rvalue falling slightly below the 0,30 cut-off point was obtained and the model was statistically significant. Upon including job insecurity, the $\mathrm{R} 2$ in creased by $31 \%$ and a $\mathrm{R}$ value of large effect $(0,63)$ was obtained. In the second step the influence of race and tenure became statistically significant as well.

Based on the above research findings, hypotheses 1, 2, 3, 4, and 5 stating that job insecurity is associated increased levels of exhaustion, cynicism, and professional efficacy, and decreased levels of affective and normative organisational commitment can be accepted. Given the lack of correlation between job insecurity and continuance commitment, hypothesis 6 is however rejected. 
TABLE 10

REgResSION ANALYSIS - DEMOgRAPHIC VARIABLES AND JOB INSECURITY: NORMATIVE COMMITMENT

\begin{tabular}{|c|c|c|c|c|c|}
\hline \multicolumn{6}{|c|}{ ANALYSIS OF VARIANCE } \\
\hline \multicolumn{6}{|c|}{ Model 1: Demographic variables } \\
\hline \multirow{3}{*}{$\begin{array}{l}\text { R: } 0,28 \\
R^{2}: 0,08 \\
\text { Adjusted R2: } 0,05 \\
\text { Standard Error: } 5,39\end{array}$} & \multicolumn{2}{|c|}{ Source of variation } & $d f$ & $\begin{array}{l}\text { Sum of } \\
\text { squares }\end{array}$ & $\begin{array}{c}\text { Mean } \\
\text { Square }\end{array}$ \\
\hline & \multirow{2}{*}{\multicolumn{2}{|c|}{$\begin{array}{l}\text { Regression } \\
\text { Residual } \\
F=2,38 p=0,048\end{array}$}} & 5 & 334,98 & 67,00 \\
\hline & & & 134 & 3888,91 & 29,02 \\
\hline \multicolumn{6}{|c|}{ Model 2: Demographic variables and job insecurity } \\
\hline \multirow{3}{*}{$\begin{array}{l}\text { R: } 0,63 \\
\mathrm{R}^{2}: 0,39 \\
\text { Adjusted } \mathrm{R}^{2}: 0,36 \\
\text { Standard Error: } 4,40\end{array}$} & \multicolumn{2}{|c|}{ Source of variation } & $d f$ & $\begin{array}{l}\text { Sum of } \\
\text { squares }\end{array}$ & $\begin{array}{l}\text { Mean } \\
\text { Square }\end{array}$ \\
\hline & \multirow{2}{*}{\multicolumn{2}{|c|}{$\begin{array}{l}\text { Regression } \\
\text { Residual } \\
F=14,28 p=0,000\end{array}$}} & 6 & 1654,81 & 275,80 \\
\hline & & & 133 & 2569,08 & 19,32 \\
\hline \multicolumn{6}{|c|}{ VARIABLES IN THE EQUATION } \\
\hline $\begin{array}{l}\text { INDEPENDENT } \\
\text { VARIABLES }\end{array}$ & B & SEB & Beta & $\mathrm{t}$ & $\mathrm{p}$ \\
\hline Gender & 0,36 & 0,95 & 0,03 & 0,38 & 0,707 \\
\hline Culture & $-1,65$ & 1,14 & $-0,13$ & $-1,44$ & 0,151 \\
\hline Age & $-0,22$ & 0,74 & $-0,04$ & $-0,30$ & 0,769 \\
\hline Qualifications & $-0,88$ & 0,42 & $-0,18$ & $-2,09$ & $0,038^{*}$ \\
\hline Tenure & 0,75 & 0,42 & 0,21 & 1,77 & 0,079 \\
\hline Gender & $-0,19$ & 0,78 & $-0,02$ & $-0,24$ & 0,812 \\
\hline Culture & 2,14 & 1,04 & 0,165 & 2,06 & 0,042 * \\
\hline Age & $-0,35$ & 0,60 & $-0,06$ & $-0,59$ & 0,559 \\
\hline Qualifications & $-0,84$ & 0,34 & $-0,17$ & $-2,45$ & $0,016^{*}$ \\
\hline Tenure & 0,78 & 0,34 & 0,22 & 2,27 & $0,025^{*}$ \\
\hline Job insecurity & $-3,71$ & 0,45 & $-0,63$ & $-8,27$ & $0,000^{*}$ \\
\hline
\end{tabular}

${ }^{*} \mathrm{p} \leq 0,05$

\section{DISCUSSION}

It was the aim of this study to determine the relationship between job insecurity, burnout and organisational commitment.

Factor analyses suggested a one-factor structure, as opposed to a two-factor structure consisting of an affective and cognitive subscale, for the JIQ. The three-factor structure of the MBI-GS was confirmed, as well as the three-factor structure of the OCQ presented. All scales demonstrated acceptable reliability coefficients.

Job insecurity was found to be significantly related to increased burnout, leading to increased exhaustion and cynicism and decreased professional efficacy. Job insecurity showed an association with decreased organisational commitment, particularly with regard to decreased affective and normative commitment, but not to continuance commitment. Job insecurity was found to hold a significant amount of predictive value with regard to burnout $(28 \%)$, exhaustion (30\%), cynicism $(38 \%)$ and decreased professional efficacy (24\%), as well as to reduced organisational commiment (32\%), affective commitment (39\%) and normative commitment (31\%), while controlling for the influence of background variables.

\section{RECOMMENDATIONS}

Research should take place in other provinces within South Africa in order to improve the generalisability of research findings. It is recommended that larger samples, which will provide increased confidence that results would be consistent across similar groups, be used. Practical significance should be determined in addition to statistical significance should be used. It is recommended that a more powerful sampling method be used and that longitudinal designs be employed, so as to enable causal inferences. Research investigating underlying causality, for example using Structural Equation Modelling, is required. Given that job insecurity was found to be related to burnout, as well as decreased organisational commitment, it is suggested that the organisation pay attention to the job insecurity levels of employees. Further research is required into ways in which job insecurity can be effectively managed in organisations. Although job insecurity was found to contribute to burnout and decreased organisational commitment in this research, little is known regarding the dynamics underlying job insecurity and how the various constructs interact.

Results indicated that the influence of culture on exhaustion, cynicism, professional efficacy and affective organisational commitment may well run through job insecurity. More research is required in this regard. As discussed above, a couple of the demographic variables which were not significant in the first step, became significant in the second step (in combination with job insecurity). The meaning of this finding is unclear and requires further investigation.

\section{REFERENCES}

Antonovsky, A. (1979). Health, stress and coping: New perspectives on mental and physical well-being. San Francisco, CA: JosseyBass.

Antonovsky, A. (1991). The structural sources of salutogenic strengths. In C.L. Cooper \& R. Payne (Eds.), Differences in the stress process. New York: Wiley.

Allen, N.J. \& Meyer, J.P. (1990). The measurement and antecedents of affective, continuance and normative commitment to the organization. Journal of Occupational Psychology, 63, 1-18.

Ashford, S. Lee, C. \& Bobko, P. (1989). Content, causes and consequences of job insecurity: A theory-based measure and substantive test. Academy of Management Journal, 32 (4), $803-829$.

Borg, I. \& Elizur, D. (1992). Job insecurity: Correlates, moderators and measurement. International Journal of Manpower, 13, 13-26.

Burke, R.J. \& Nelson, D. (1998). Mergers and acquisitions, downsizing and privatization: A North American perspective. In M.K. Gowing J.D. Kraft \& J.C. Quick (Eds.), The new organizational reality: Downsizing, restructuring and revitalization (pp. 21-54). Washington, DC: American Psychological Association.

Burns, N. \& Grove, S.K. (1993). The practice of nursing research: Conduct and utilization (2nd ed.). Philadelphia: Saunders Publishers.

Carrell, M.R., Elbert, N.F., Hatfield, R.D., Grobler, P.A., Marx, M. \& van der Schyf, S. (1999). Human Resource Management in South Africa. Cape Town: Prentice Hall.

Chow, I.H. (1994). Organisational commitment and career development of Chinese managers in Hong Kong and Taiwan. International Journal of career management, 6 (4), 3-9.

Clark, L.A. \& Watson, D. (1995). Constructing validity: Basic issues in objective scale development. Psychological Assessment, 7, $309-319$.

Cohen, J. (1988). Statistical power analysis for the behavioural sciences (2nd ed.). Hillsdale, NJ: Lawrence Erlbaum \& Associates. 
Cooper, C.L. \& Jackson, S. (1997). Creating tomorrow's organizations: A handbook for future research in organizational behavior. Chichester, UK:Wiley.

Cordes, C.L. \& Dougherty, T.W. A review and integration of research on job burnout, Academy of Management Review, 18 (4), 621-656.

Davy, J.A., Kinicki, A.J. \& Scheck, C.L. (1997). A test of job insecurity's direct and mediated effects on withdrawal cognitions. Journal of Organisational Behaviour, 18, 323 - 349.

De Cotiis, T. \& Summers, T. (1987). A path analysis of a model of the antecedents and consequences of organizational commitment, Human Relations, 40 (7), 445470.

Dekker, S.W, \& Schaufeli, W.B. (1995). The effect of job insecurity on psychological health and withdrawal: A longitudinal study. Australian Psychologist, 30, 57-63.

De Witte, H. (1997, April). Long term job insecurity as a stressor: It's impact on satisfaction and commitment. Paper presented at the $8^{\text {th }}$ European Congress on Work and Organizational Psychology, Verona, Italy.

De Witte, H. (2000). Arbeidethos en jobonzekerheid: Meting en gevolgen voor welzijn, tevredenheid en inzet op het werk. In R Bouwen, K De Witte., H De Witte \& T Taillieu. (Reds.), Van groep tot gemeenskap. Liber Amicorum Prof. Dr. L. Lagrou. Leuven: Garant.

Elbert, J. (2002). Job insecurity, and psychological strengths of service workers in a parastatal. Unpublished master's dissertation, Vaal Triangle Campus of the Potchefstroom University, Vanderbijlpark.

Ferrie, J., Shipley, M.J., Marmot, M.G., Stansfield, S. \& Smith, G.D. (1998). The health effects of major organizational change and job insecurity. Social Science and Medicine, 18, $155-170$.

Gerber, P.D., Nel, P.S. \& Van Dyk, P.S. (1999). Human Resource Management (4th ed.). New York: Oxford.

Greenhalgh, L. \& Rosenblatt, Z. (1984). Job insecurity: Toward conceptual clarity. Academy of Management Review, 9 (3), $438-448$

Hartley, J., Jacobson, D., Klandermans, P.G. \& van Vuuren, C.V. (1991). Job insecurity: Coping with jobs at risk. London: Sage.

Heany, C.A., Israel, B.A. \& House, J.S. (1994). Chronic job insecurity among automobile workers: Effects on job satisfaction and health. Social Science and Medicine, 38, 1431 $-1437$.

Heymans, D.R. (2002). The relationship between job insecurity, job satisfaction and organisational commitment of maintenance workers in a parastatal. Unpublished master's dissertation, Vaal Triangle Campus of the Potchefstroom University, Vanderbijlpark

Hitt, M.A., Keats, B.W., Harback, H.F. \& Nixon, R.D. (1994). Rightsizing, building and maintaining strategic leadership: A long-term competitiveness. Organizational Dynamics, 23, 18-32.

Hobfoll, S.E. (1989). Conservation of resources: A new attempt at conceptualizing stress. The American Psychologist, 44, 513524.

Howard, A. (1995). The changing nature of work. San Francisco, CA: Jossey-Bass.

Leiter, M.P. \& Maslach, C. The impact of interpersonal environment on burnout and organizational commitment.; Journal of Organizational Behavior, 9 (4), 297-308.

Lok, P. \& Crawford, J. (2001). Antecedents of organizational commitment and the mediating role of job satisfaction, Journal of Managerial Psychology, 16 (8), 594-613.

Lord, A. \& Hartley, J. (1998). Organizational commitment and job insecurity in a changing public service organization. European Journal of Work and Organizational Psychology, 7 (3), 341-354.

Maslach, C., Jackson, S.E. \& Leiter, M.P. (1997). Maslach Burnout Inventory: Third edition. In $\mathrm{C}$ Zalaquett, $\mathrm{R}$ Wood \& $\mathrm{M}$ Lanham. (Reds.), The truth about burnout. San Francisco, CA: Jossey Bass.
Maslach, C. \& Leiter, M.P. (1997). The truth about burnout. San Francisco, CA: Jossey-Bass.

Maslach, C., Schaufeli, W.B. \& Leiter, M.P. (2001). Job burnout. Annual Review of Psychology, 52, 397-422.

Maslach, C. \& Pines, A. (1977). The burnout syndrome in the day care setting. Child Care Quarterly, 6, 100-113.

Mathieu, J. \& Zajac, D. (1990). A review of meta-analysis of the antecedents, correlates and consequences of organizational commitment, Psychological Bulletin, 108 (2), 171-194.

McDonald, D.J. \& Makin, P.J. (2000). The psychological contract, organizational commitment and job satisfaction of temporary staff. Leadership and Organization Development Journal, 21 (2), 84-91.

Michaels, P. (1994). An expanded conceptual framework on organizational commitment and job satisfaction for salesforce management, Journal of Business and Society, 7 (1) 42-67.

Mowday, R.T., Porter, L.W. \& Steers, R.M. (1982). Organisational linkages. The psychology of commitment, absenteeism and turnover. NY: Academic Press.

Mowday, R.T., Steers, R.M. \& Porter, L.W. (1979). The measure of organizational commitment. Journal of Vocational Behavior, 14, 224-247.

Nunnally, J.C. \& Bernstein, I.H. (1994). Psychometric theory (3rd ed.). NY: McGraw-Hill.

Probst, T.M. (1999). Antecedents and consequences of job insecurity: Development and test of an integrated model. (Doctoral dissertation, University of Illinois at Urbana-Champaign, 1998). Dissertation Abstracts International, 6102

Rosenblatt, Z., \& Ruvio, A. (1996). A test of a multidimensional model of job insecurity: The case of Israeli teachers. Journal of Organizational Behaviour, 17, 587-605.

Rosenblatt, Z., Talmud, I. \& Ruvio, A. (1999). A gender-based framework of the experience of job insecurity and its effects on work attitudes. European Journal of Work and Organisational Psychology, 8 (2), 197-217.

Rothmann, S. (2003). Burnout and engagement: A South African perspective. South African Journal of Industrial Psychology, 2, $16-25$.

Schaufeli, W.B. \& Buunk, B.P. (2002). Burnout: An overview of 25-years of research and theorizing. In $\mathrm{M}$ Schabracq, C Cooper \& C Winnubst (Eds.), Handbook of work and health Psychology. Chichester, UK: Wiley.

Selepe, C. (2004). Job insecurity, job satisfaction, work wellness and organisational commitment in a petroleum/oil company. Unpublished master's dissertation, Vaal Triangle Campus of the Potchefstroom University, Vanderbijlpark.

Shaughnessy, J.J. \& Zechmeister, E.B. (1997). Research methods in psychology (4th ed.). NY: McGraw-Hill.

Sparks, K., Faragher, B. \& Cooper, C.L. (2001). Well-being and occupational health in the 21st century workplace. Journal of occupational and organizational psychology, 74, 489-509.

SPSS Inc. (2003). SPSS 12.0 for Windows. Chicago, IL: Author

Storm, K. (2002). Burnout and work engagement in the South African Police Service. Published doctorate dissertation, Potchefstroom University, Potchefstroom.

Suliman, A.M., \& Iles, P.a. (2000a). Is continuance commitment beneficial to organizations? Commitment - performance relationship: A new look. Journal of Managerial Psychology, 15 (5), 407-426

Van Vuuren, T. (1990). Met ontslag bedreigd. Werknemers in onzejerheid over hun arbeidsplaats bij veradneringen in de organisatie. Amsterdam: VU Uitgeverij.

Whitfield, B. (2003, June 10). SA banks slash jobs. Citizen, p. A14.

Wissing, M.P. \& Van Eeden, C. (2002) Empirical classification of the nature of psychological well-being. South African Journal of Psychology, 32, 32-44. 